\title{
An Analytical View on Resilience Urban Planning, Focusing on Urban Transport Systems and Climate Change
}

\author{
By Peyman Khodabakhsh* \\ Samira Mashayekhi ${ }^{\dagger}$ \\ Behzad Malekpour Asl
}

\begin{abstract}
Increasing economic, social and spatial vulnerabilities and pressures due to incorporation of urban areas into the new global economy and opening the door to external pressures necessitate building resilient urban systems. The entrepreneurial logic in property markets decreases the opportunity for public concerns, and unequal power relations and the privatization of the state make proactive measures to unexpected crisis and hazards difficult. Moreover, increasing ecological vulnerabilities require connecting planning and science of ecology and enhancing ecological resilience of urban systems. Over the coming decades, the need to build capacity for greater resilience will require our cities to develop strategies for coping with the future shocks and stresses to our urban infrastructure systems associated with climate change. Our cites will also have to find ways to significantly reduce their dependence on oil and other fossil fuels - to find ways to become more self-sufficient and energy efficient in the face the economic realities of energy transition associated with energy scarcity (often now referred to as "peak oil"). In fact, an effective urban planning could play an important role in facilitating the development of a greater capacity for future resilience. Therefore the main debate in this paper is to survey and analyze the interrelations of efficiency and resiliency in urban transport system as well as developing roadmaps and principles for resilient urban transport system with a focus on energy consumption and its subsequent ecological impacts. This paper aims at developing a conceptual framework and principles for both resilient and energy efficient urban transport system.
\end{abstract}

${ }^{*}$ PhD Candidate, Technical University of Berlin, Germany.

${ }^{\dagger} \mathrm{PhD}$ Candidate, Technical University of Berlin, Germany.

${ }^{\star}$ PhD Candidate, Shahid Beheshti University, Iran. 


\section{Introduction}

Since the late 1970s, Neo-liberalization and market-friendly policies have been affecting the way cities develop and function. Neoliberal principles based on market reliance seem to take over or manipulate the decision-making powers in urban development and create uncoordinated state interventions (Peck et al. 2009). Increasing neo-liberalization and entrepreneurialisation cause serious problems in the governance of cities, while the responsibilities, tasks and developments of the public sector are decentralized or privatized; economic activities are deregulated, and welfare services are replaced by workfares social policies that favor innovative and competitive economic development (Purcell 2009, Leitner et al 2007, Harvey 2005, Jessop 1993).

It is clear that the neo-liberalization of social, economic and political processes affects not only urban development and governance but also planning discourses and practices, which are pushed in more market-oriented directions. This leads to a fragmentation of the variety of planning approaches to the neo-liberalization of dominant economic policies in urban areas (Purcell 2009), and the forces of neo-liberalization slowly take over each planning sub field. Since the 1980s, it has been possible to observe uncoordinated and even chaotic actions of fragmented public policies, programs and projects, as well as plans. Increasingly opportunity-led approaches of planning institutions and an unequal redistribution of benefits and welfare as a result of the deregulation of the property and land markets became the main facets of the contemporary period. This situation came about mainly due to the blurred boundaries between the public sector and private markets, and the resulting vague position of planning institutions (Alexander 2008). There has been an increase in the number of disturbances that put significant pressure on urban systems. As urban systems become more open to global pressures, urban ecological systems are affected more by global growth dynamics. This not only increases their exposure to ecological pressures but also hinders the sustainability of economic and social development. The concurrent economic and environmental crises experienced in recent decades have enhanced the perceived sense of vulnerability and have "increased the sense of risk and the perception that processes associated with globalization make places more permeable to the effects of what were once thought to be external processes" (Christopherson et al 2010). Considering the novelty of the concept, there exists a gap in recent studies, mainly in regard to how integrate resiliency and energy efficiency principles in Urban and transport planning system, with a focus on spatial oriented criteria. Therefore the paper is targeted to develop a basis to enhance resiliency and efficiency of urban transport systems. The integrated urban transport planning principles are the main focal point in this paper. 


\section{Research Aim and Process}

The main aim of the research is to shed more light on the complex theoretical background and principles of resiliency in urban context with focus of urban transport systems. Furthermore to address strategies for urban transport systems aiming at reducing their dependence on oil and other fossil fuels - to find ways to become more self-sufficient and energy efficient in the face the economic realities of energy transition associated with energy scarcity (often now referred to as "peak oil"). Depicted in figure 1 is the process of the research. For this aim, conceptual frameworks of resiliency as well as its key elements are surveyed and urban planning transport system is investigated among the various interaction fields. This led to a survey on necessities within the resilient urban transport system aiming at developing resilient transport planning strategies

Figure 1. The Study Framework and Procedure

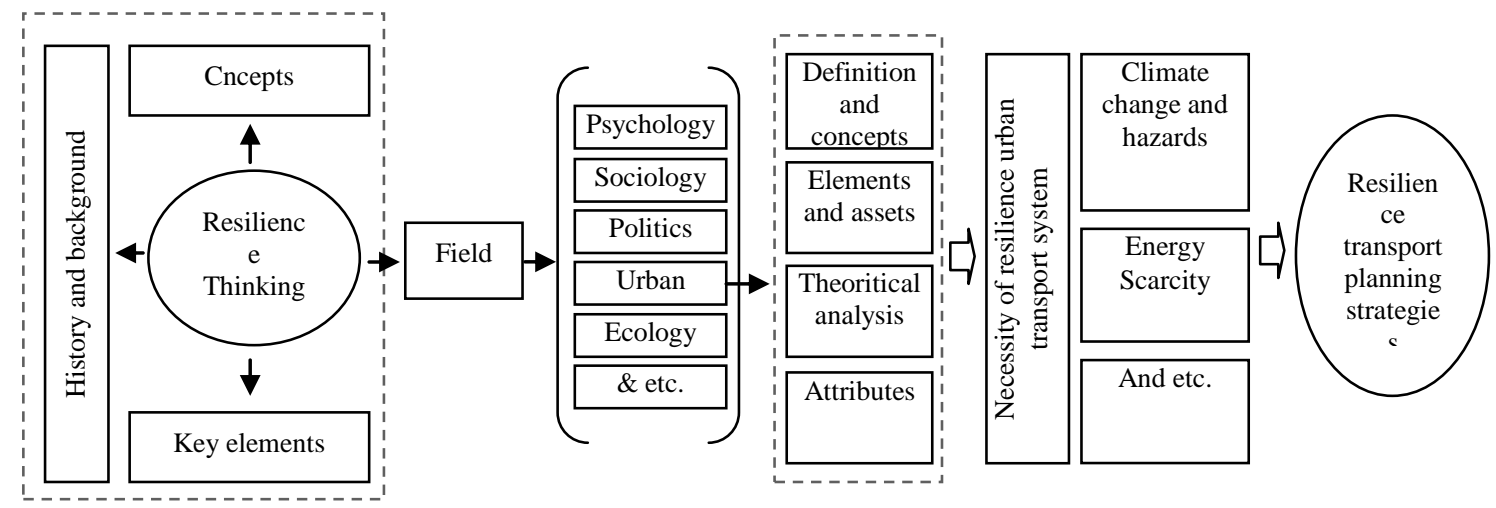

\section{Resiliency Concept}

Resilience in systems, broadly defined, refers to the capacity of a system to continue to function given external shocks. In contrast, vulnerability is most naturally used as an antonym of resilience. Seeming paradoxes with this usage highlights that "resilience" is highly contextual. Ascriptions (and comparisons) only make sense after one has specified resilience to what (Martin-Breen et al. 2011). On the other hand, sustainability as a broader concept is about preservation of something or some function, usually used in a way so as to imply the desirability of what is preserved. Sustainability may be promoted in ways that don't involve resilience: risk aversion, crisis recovery, and increased efficiency. If one adopts, however, the additional thesis that disruptive events of a certain magnitude cannot be avoided, then sustainability over time requires resilience at each time. The relationship between these two terms is, then, theoretical, not semantic (Martin-Breen et al. 2011). In resiliency literature, two key concepts are fundamental for surveys in systems. Adaptive capacity refers to the capability of a particular system to effectively cope with shocks. 
Given that the term is applied to a particular system, it is implicitly focused on smaller time scales. Transformability, on the other hand, refers to the capability of a system to reorganize into a new system when it can no longer cope in its existing form. If we refer to the set of actors and relationships that constitute the structure of a particular system as that systems identity, then transformability refers to the ability of a system to change identity. Implicitly, such changes occur over long periods, and thus transformability is an aspect of resilience that is relevant over longer periods (larger time scales) (MartinBreen and Marty Anderies 2011).

Resilience has, in the past four decades, been a term increasingly employed throughout a number of sciences: psychology and ecology, most prominently. Increasingly one finds it in political science, business administration, sociology, history, disaster planning, urban planning, and international development. The shared use of the term does not, however, imply unified concepts of resilience nor the theories in which it is embedded. Different uses generate different methods, sometimes different methodologies. Evidential or other empirical support can differ between domains of application, even when concepts are broadly shared (Martin-Breen and Marty Anderies 2011). At the simplest level, increased resilience implies bouncing back faster after stress, enduring greater stresses, and being disturbed less by a given amount of stress. "Stress" can imply either chronic difficulty or an acute crisis. In this basic sense, to be resilient is to withstand a large disturbance without, in the end, changing, disintegrating, or becoming permanently damaged; to return to normal quickly; and to distort less in the face of such stresses. The main characteristics of a resilient system is stated in table 1.

Table 1. Characteristics of a Resilient System

\begin{tabular}{|c|l|}
\hline Characteristics & \multicolumn{1}{|c|}{ Description } \\
\hline Adaptive capacity & $\begin{array}{l}\text { Equipping urban systems to deal efficiency with slow and } \\
\text { radical changes }\end{array}$ \\
\hline Self-organization & $\begin{array}{l}\text { The process of internal organization within a system } \\
\text { without being guided or managed by an outside source. }\end{array}$ \\
\hline Transformability & $\begin{array}{l}\text { Having the capacity to create a fundamental new system } \\
\text { when the ecological, economic and social conditions } \\
\text { make the existing system untenable. }\end{array}$ \\
\hline
\end{tabular}

Source: Martin- Breen and Marty Anderies 2011

\section{Urban Resilience Paradigm}

The concept of resilience, in the urban context, was borrowed from studies on the manner in which ecological systems cope with stresses and disturbances caused by external factors (Davic and Welsh 2004). From an ecological perspective, Holling (1973), who may be the first to define it (Barnett 2001, Carpenter et al. 2001), suggests that resilience is "the persistence of relationships within a system" and "the ability of these systems to absorb changes of state variables, driving variables, and parameters, and still persist" 
(Holling 1973: 17). In other words, resilience is "the capacity of a system to undergo disturbance and maintain its functions and controls" (Gunderson and Holling, 2001).

In another word, increasing economic, social and spatial vulnerabilities due to incorporation of urban areas into the new global economy and opening the door to external pressures necessitate building resilient urban systems. The entrepreneurial logic in property markets decreases the opportunity for public concerns, and unequal power relations and the privatization of the state make proactive measures to unexpected crisis and hazards difficult. Moreover, increasing ecological vulnerabilities require connecting planning and science of ecology and enhancing ecological resilience of urban systems, and considering the impact of already-foreseen or unforeseen threats to ecosystems.

A resilient system is defined by its two main features: its ability to absorb change and disturbance, and the persistence of systems while retaining its basic functions and structure (Walker et al. 2006); together with the ability to survive, adapt and transform itself (Ludwig et al. 1997). The attributes above define a possible choice in building a planning framework: whether to follow conservative or radical constructs of resilience (Raco and Street 2012). The former view of resilience allows a return to the steady state that existed before the external shock threatened to bring radical and fundamental change, while in contrast the latter interpretation sees resilience as a dynamic process involving the rejection of the status quo, as there can be no return to the circumstances that actually caused the problem in the first place (Raco and Street 2012). The latter definition, accepted here as the core of the resilience planning paradigm, can be defined with respect to three aforementioned dynamic assets of the urban systems: adaptive capacity, self-organization and transformability, rather than characteristics connected to the steady-state condition. Evaluating urban systems with respect to these assets enables one to determine the critical issues for resilience planning. First, it has to be dynamic, not seeking to return to stable equilibrium under external disturbances and changes due to local dynamics, but adapting and adjusting to changing internal or external processes. Secondly, it has to consider economic, social and ecological heterogeneity by concentrating on not only the form but also function and process of urban systems (Pickett et al. 2004). Thirdly, resilience planning needs to be based systems analysis, which will enable to define the points and issues of vulnerability of urban systems and to be focused on key issues, being those related to the adaptive and transformative capacities of urban areas in terms of determining strengths and weaknesses in the context of opportunities and threats. The aforementioned concepts are reflected in table 2, where different planning paradigm are compared. 
Table 2. The Resilience Paradigm and its Major Characteristics

\begin{tabular}{|c|c|c|c|}
\hline & $\begin{array}{l}\text { RATIONAL } \\
\text { COMPREHENSIVE } \\
\text { PLANNING }\end{array}$ & $\begin{array}{l}\text { COMMUNICATIVE/ } \\
\text { COLLABORATIVE } \\
\text { PLANNING }\end{array}$ & $\begin{array}{l}\text { RESILIENCE } \\
\text { PLANNING }\end{array}$ \\
\hline RATIONALITY & $\begin{array}{l}\text { Instrumental } \\
\text { rationality }\end{array}$ & $\begin{array}{l}\text { Communicative } \\
\text { rationality }\end{array}$ & $\begin{array}{l}\text { Integrative rationality } \\
\text { A framework that } \\
\text { combines instrumental } \\
\text { and communicative } \\
\text { rationality }\end{array}$ \\
\hline ACTORS & $\begin{array}{l}\text { Individuals/ } \\
\text { technicians }\end{array}$ & $\begin{array}{l}\text { Individuals } \\
\text { interactive groups }\end{array}$ & $\begin{array}{l}\text { Interdisciplinary } \\
\text { groups with technical } \\
\text { expertise } \\
\begin{array}{ll}\text { Social groups as } \\
\text { learning agents of } \\
\text { change }\end{array} \\
\end{array}$ \\
\hline $\begin{array}{l}\text { RELATIONS BETWEEN } \\
\text { ACTORS/ISSUES OF } \\
\text { POWER }\end{array}$ & Defining goals for all & Consensus generation & Commitment \\
\hline TIME PERSPECTIVE & Medium to long term & Short term & $\begin{array}{l}\text { Long term perspective. } \\
\text { Systems approach and } \\
\text { immediate action }\end{array}$ \\
\hline CONCERN & Problem solving & $\begin{array}{l}\text { Collective agreement/ } \\
\text { decision }\end{array}$ & $\begin{array}{l}\text { Issued raised under the } \\
\text { instrumental } \\
\text { rationality act as } \\
\text { constraints }\end{array}$ \\
\hline AIM & $\begin{array}{l}\text { Defining the most } \\
\text { effective actions/ to } \\
\text { achieve goals }\end{array}$ & $\begin{array}{l}\text { Consensus, mutual } \\
\text { understanding }\end{array}$ & $\begin{array}{l}\text { Defining priorities for } \\
\text { a no-regret situation } \\
\text { preparedness for both } \\
\text { slow and major } \\
\text { disturbances }\end{array}$ \\
\hline OUTPUT & $\begin{array}{l}\text { Decisions: based on } \\
\text { technical knowledge }\end{array}$ & $\begin{array}{l}\text { Collective decision } \\
\text { based on socially } \\
\text { constructed values }\end{array}$ & $\begin{array}{l}\text { Flexible solutions } \\
\text { depending upon spatial } \\
\text { heterogeneity function } \\
\text { and temporal change }\end{array}$ \\
\hline CONTEXT/SUBSTANCE & $\begin{array}{l}\text { Comprehensive } \\
\text { decisions }\end{array}$ & $\begin{array}{l}\text { Context as an outcome } \\
\text { of process }\end{array}$ & Red tape and priorities \\
\hline VALUE SYSTEMS & Individual values & $\begin{array}{l}\text { Socially constructed } \\
\text { values }\end{array}$ & $\begin{array}{l}\text { Universal values for } \\
\text { common benefits }\end{array}$ \\
\hline $\begin{array}{ll}\text { BASES } & \text { OF } \\
\text { EVALUATION } & \text { OF } \\
\text { OUTPUTS } & \\
\end{array}$ & Efficiency & $\begin{array}{l}\text { Consensus-based } \\
\text { values }\end{array}$ & Resilience attributes \\
\hline
\end{tabular}

Source: Eraydin and Tasan- Kok 2013

\section{Resilience Urban Transport System (Focusing on Energy Crises)}

Integrated response strategies to disasters and risks are needed in order to create resilient communities capable of facing risks with greater flexibility (Reis 2013, Sapountzaki et al. 2011). This entails linking actors and policies throughout a disaster management cycle that has the following stages: (a) reconstruction and recovery, concerning the long-term activities aimed at returning an area to 'normality' after severe devastation; (b) pre-disaster or preventive planning covering activities which range from the construction of defensive engineering works to land-use planning and elaboration of evacuation plans; (c) preparedness reflecting alertness immediately before the onset of a hazard; and (d) response referring to reaction activities immediately 
before and after the event and (emergency) relief operations. The problem is that, within this disaster management cycle, spatial planning (and transportation planning) is largely absent (Nakanishi 2013: 181-182). The concept of resilience transportation planning giving structure to urban development had tended to be ignored traditionally by planners who recognized only the significance of response referring to reaction activities immediately before and after the event and (emergency) relief operations. However, the new transportation planning theory is in synchronization with this perspective, and in that context, urban development may be seen as referring to increasing the quality of pre-disaster or preventive planning covering activities associated with changes but not necessarily designing of roads, in the quantity and nature of local access, and in the quantity transportation services produced locally. This conception of transit gives a fluid and dynamic meaning to concepts of "urban development", emphasizing the importance of empirical analysis of the relations between transportation factors and resilience flexibility transformative drivers. Underpinning legacy forces may hold some positions, discourses and practices in place beyond any immediate functional relationship to urban form development. Or the ongoing interaction between actors at the urban region level and strategic maneuvers to mobilize of urban resources exert a significant effect on urban transportation system efficiency. This conception provides a rich way to analyze the dynamics of interaction of context and innovative action (Campanella 2006, Ganor and Ben-lavy 2003, Godschalk 2003). Because of these facts, the transportation science literature on flexibility and efficiency has mainly focused on the effects at the sub-urban region level; highlighting the positive role that resilience factor may have on efficiency through different channels. For example, R\&D activities are required to be able to quickly and effectively adapt products to the needs and specificities of new transportation model for facing risks with greater flexibility. Sustainable transportation planning which contain resilience concept has become a global issue since its introduction more than fifteen years ago by the World Commission on transportation systems. The concept emerged to foster a balance consideration of social, economic and environmental consequences of development activities. Despite the pervasiveness of the principles of sustainability, only few communities have been able to develop strategies of fostering sustainability and these few communities and regions are mainly in the developed countries. This is due to the difficulties in operationalizing sustainability principles and the institutional contexts of implementing these principles in transportation context. Different approaches and frameworks have been developed to move communities towards transportation sustainability. Most of the approaches are developed on a framework of impact assessment, monitoring, indicators and targets/benchmarking. In addition, cities and spatial planning are given special attention by these approaches. The city has attracted attention because of the response strategies to disasters and risks are needed in order to create resilient communities that result from rapid urbanization and continued increase in urban population. That is, sizeable number of people is affected by urban 
disaster problems. Spatial resilience transportation planning has a stake in promoting sustainability as plans, policies and programs that determines land uses and risk management impacts are products of the transportation planning process. The focus on spatial urban transportation planning for the achievement of sustainable communities has been on the two major aspects of planning; the planning process and the outcome of planning (Suarez et al. 2005).

\section{Energy Debate and Resiliency of Transport Systems}

Energy is central to addressing major challenges of the 21st Century, challenges like climate change, economic and social development, human wellbeing, sustainable development, and global security which brings the necessity of resilience planning in all aspects. Today the world of energy has many of the features established in the 20th century. Energy consumption grows on average at $2 \%$ per year; most of it (80\%) originates in fossil fuels which is driven by population growth and economic growth, now predominantly in developing countries and high levels of consumption in the developed countries. On the other hand, 3 billion people don't have access to basic energy services and have to cook with solid fuels.

Transport plays a fundamental role in the development and economic prosperity of urban areas because commercial organization, the location of industry, housing, and all other general services are transport dependent. At the present rate of world urbanization, cities will require increased transport services to make accessible the supplies needed for their physical expansion and to support economic development. The challenge of developing resilient low-carbon transport systems will define the possibility of guaranteeing life in urban places as economically viable, socially constructive, environmentally safe, and, in general, qualitatively enjoyable spatial configurations. From a climate change mitigation perspective, one can categorize emissions from transport into carbon intensity of energy, energy intensity of transport, and total transport demand (Schipper and Marie-Lilliu 1999, Creutzig et al. 2011a). Both the decision to travel or not and the modal choice for this travel affects fuel consumption, and therefore carbon emissions. With a focus on urban road transport, a transition to sustainable transport can follow the "Avoid, Shift, Improve" framework (GTZ 2007, Bongardt at al. 2010). This framework considers different major principles under which diverse policy instruments (Planning, Regulatory, Economic, Information, Technological) are grouped interventions to mitigate GHG emissions from transport, assuming different emphases for developed and developing countries (Dalkmann and Brannigan 2009)."Avoid" and "Shift" influence the level of activity and structural components that link transport to carbon emissions. "Improve" focuses on technological options, not only with respect to climate mitigation but also taking into account local environmental conditions and social.

Energy use for transport is a major source of air pollutants in all communities, but with wide variations depending on vehicle densities, 
congestion, fuels, and engine technologies. Vehicle emissions have special significance from a human health perspective because they occur in close proximity to people, enhancing the fraction of emissions that is inhaled. In developed cities, where industrial and uncontrolled point source combustion is relatively rare, vehicle emissions can be the dominant local air pollution source (Qin et al. 2006). The situation in developing cities is far more complicated, with much higher levels of air pollution emissions overall, from a wide range of sources. However, vehicles play an important and probably increasing role in urban air pollution in developing cities (Kinney et al, 2011).

Reducing per vehicle emissions, either through fuel or technology interventions is a relatively fast and economical approach for achieving significant improvements in urban air quality. Another challenging but ultimately more sustainable solution is to address growing road congestion by providing public transportation options. This has the potential to reduce the rapid rise in private vehicle use being seen in many developing cities, which is far outpacing road infrastructure. Many developing-world cities are examining urban transport reform, with some success stories (e.g., Brazil or Bangkok).

Vehicles can affect air quality in other ways besides their engine emissions. Road dust can be a serious nuisance in developing-world cities, and often carries health risks due to toxic materials re-suspended with the dust, including asbestos from brake linings, lead from tire weights, and oil from leaking tanks.

From the energy perspective, the concurrent fast expansion of population, urbanization, and global mobility has multiplied the world's demand for fuels for transportation and city-wide energy services. In fact, energy use in the transport sector in 2007 was high, $28 \%$ of total final energy use. During the last several decades, the energy use of transport sectors in both organizations for Economic Co-operation and Development (OECD) and non-OECD countries has increased substantially. In developing countries, the increase in recent years has become more prominent due to rapid urbanization and motorization. And, although a major increase in energy use was caused by road transport, the actual phenomenon of motorization is quite different between OECD and nonOECD countries. Non-OECD countries started later and still show motorization rates significantly below OECD countries. However, the speed of their concurrent urbanization and motorization is unrivalled, especially in China, and puts significant demands on adapting transport infrastructures. A single fossil resource- petroleum- supplies $95 \%$ of the total energy used by world transport. This dependence results in two major areas of global concern: the long-term security of energy supplies and the fast rising contribution of the transport sector to greenhouse gas (GHG) emissions (IEA 2009a, Stern 2007). The carbon dioxide (CO 2) emissions and energy use of different transport subsectors are proportional. The transport sector has the highest rate of growth in energy use and related CO 2 emissions of all final end-user sectors. This rate is expected to increase up to $1.7 \%$ a year between 2004 and 2030 (IEA 2009a). 1 In 2007, the global transport sector produced 6.6 Gt CO 2 emissions, corresponding to $23 \%$ of world energy-related $\mathrm{CO} 2$ emissions and, road 
transport, mostly passenger transport, accounts for $73 \%$ of this total. A much higher rate of growth of 3.7\%/year (between 1990-2003) corresponds to freight transport; this trend is expected to continue (McKinsey Global Institute 2009). Urbanization has been extremely rapid in the past 60 years, with a $2.6 \%$ annual average growth rate (UN 2009). In 2010, twenty one cities reported having a population over 10 million compared with two cities in 1950 (UNDP 2010). Rapid growth in suburban areas and the rise of "edge cities" in the outer suburbs has been a common form of development facilitated by the rise of personalized motor transportation. The greater distances replicated through the low-density development discourage walking and bicycling as a share of total travel and are not easily served by public transport (WBCSD 2002). A growing demand for travel and a declining share in the use and quality of public transportation services have been the observed result across developed and developing cities alike (Gwilliam 2005, Tiwari 2006, Hidalgo and Carrigan 2010, Buehler and Pucher 2011).

\section{A Roadmap to Resilient Urban Transport System}

Urban planning, when well integrated with transport investment, is critical in terms of allowing a greater level of public transport usage, walking and cycling, and more localized trip patterns (Hickman et al. 2013, Banister 2008). They consider the role of urban form in transport planning and investments offering possibilities for a changed level of investment in public transport, alongside efforts to improve facilities for walking and cycling, and a supportive urban structure. Urban form, urban structure and mobility are important terms in planning for mobility with strong linkages encompassing resiliency and efficiency which is also associated with socio-economic and demographic characteristics. In the frame of the aforementioned issues, three main roadmaps for resilient urban transport systems are derivable. These roadmaps are presented in the frame of table 3. 
Table 3. Aims, Roadmaps and General Criteria of Resilient Urban Transport System

\begin{tabular}{|c|c|c|}
\hline AIMS & SYSTEM ROADMAPS & SYSTEM CRITERIA \\
\hline \multirow{2}{*}{$\begin{array}{l}\text { REDUCTION OVERALL } \\
\text { ENERGY REQUIREMENTS }\end{array}$} & $\begin{array}{l}\text { Reducing the energy demand of } \\
\text { our existing urban fabric }\end{array}$ & \multirow{6}{*}{$\begin{array}{l}\text { - Multimodal system, } \\
\text { - Multi-objective system } \\
\text { - Multi-functional system } \\
\text { - Dynamic system and sub- } \\
\text { systems } \\
\text { - Context oriented system } \\
\text { based on the culture and } \\
\text { socio-economic status of } \\
\text { users }\end{array}$} \\
\hline & $\begin{array}{l}\text { Reducing our consumption of } \\
\text { fossil fuels for transportation }\end{array}$ & \\
\hline \multirow{2}{*}{$\begin{array}{l}\text { INCREASING KEY } \\
\text { INFRASTRUCTURE } \\
\text { CAPACITY }\end{array}$} & $\begin{array}{l}\text { Re developing the public } \\
\text { transport infrastructure }\end{array}$ & \\
\hline & $\begin{array}{l}\text { Making transport infrastructure } \\
\text { more flexible in case of a shock }\end{array}$ & \\
\hline \multirow{2}{*}{$\begin{array}{l}\text { RE-LOCALIZATION OF } \\
\text { KEY FUNCTIONS INTO A } \\
\text { CITY }\end{array}$} & $\begin{array}{l}\text { Integrating the city background } \\
\text { and culture }\end{array}$ & \\
\hline & $\begin{array}{l}\text { Re allocating and re planning of } \\
\text { existing urban travel generators }\end{array}$ & \\
\hline
\end{tabular}

Source: Authors

\section{Resilient Urban Transport System Principles}

Evaluating urban transport systems with respect to the resiliency assets enable one to determine the critical issues for resiliency planning as the following:

- First, it has to be dynamic, not seeking to return to stable equilibrium under external disturbances and changes due to local dynamics, but adapting and adjusting to changing internal or external processes.

- Secondly, it has to consider economic, social and ecological heterogeneity by concentrating on not only the form but also function and process of urban systems.

- Thirdly, resilience planning needs to be based systems analysis, which will enable to define the points and issues of vulnerability of urban systems and to be focused on key issues, being those related to the adaptive and transformative capacities of urban areas in terms of determining strengths and weaknesses in the context of opportunities and threats.

A comprehensive list of principles of resilient and efficient urban transport system is stated in table 4 . 
Table 4. Proposed Resilience Urban Transport Principles

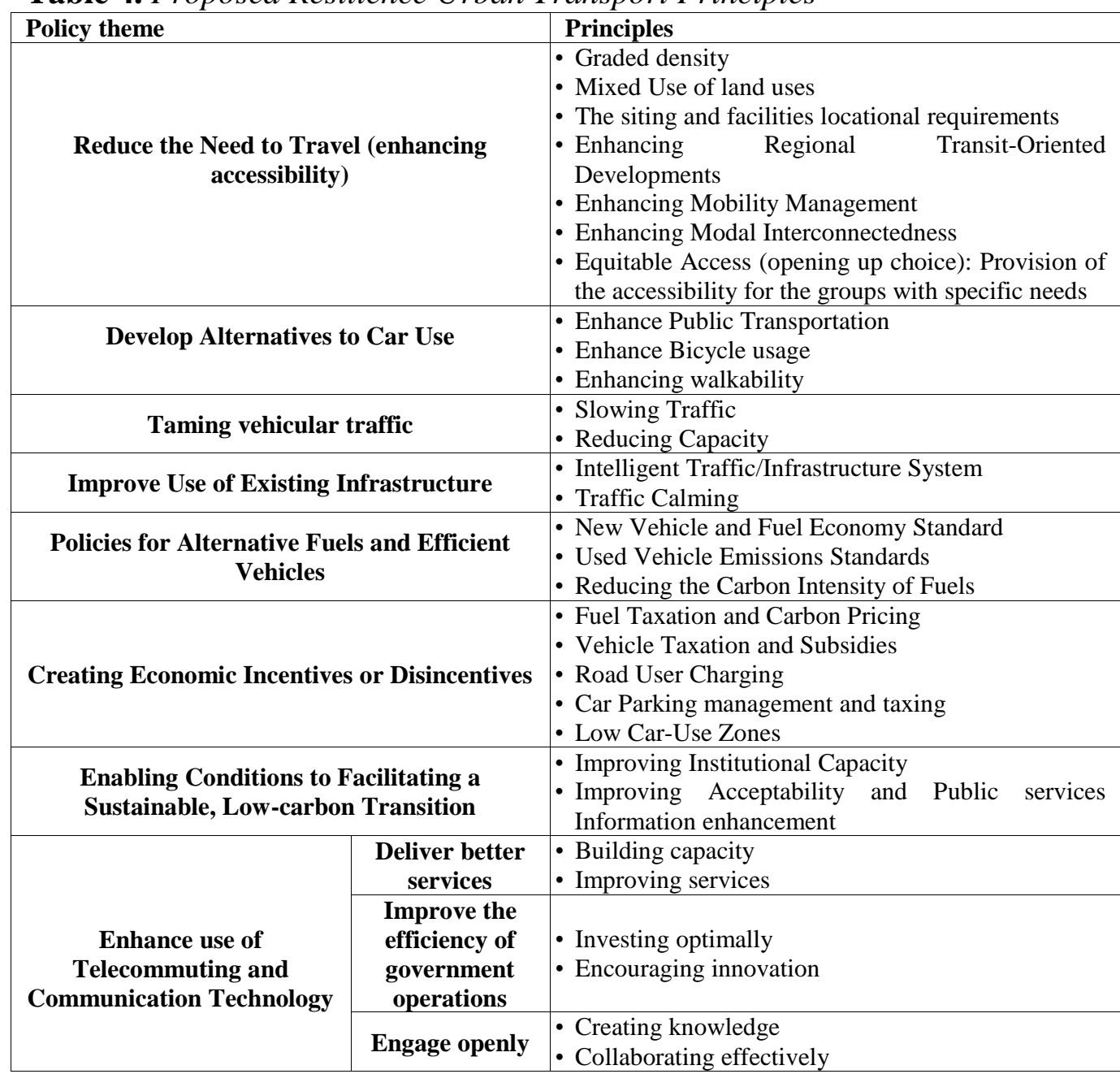

Source: Authors

\section{Conclusion}

In recent years, transportation planners have increasingly resorted to resilience concept in order to cope with the need to integrate differentiated sources of knowledge and implement a faster and cheaper innovative process in for transportation efficiency improvement. Resilience and the urban transportation tackles the topical idea of resilience in the urban context, but its application in this paper is different to that which most approaches adopt, in that it focuses on the governmental and societal implementations of methods to manage risks, enhance efficiency and improving the urban life. Here the idea of resilience is developed within a theoretical framework that centers upon the usage of resilience urban transport principles to deconstruct the policies and practices of resilience in response to risks, as acted out in urban environments. The enactment of resilience in its diverse forms is illustrated through examples ranging from reduce the need to travel (enhancing accessibility) to enhancing 
use of telecommuting and communication technology. This theoretical approach is deployed to unpack the meaning and implementations of methods said to increase resilience to risk, both physical and societal, and the impacts that this has on the day-to-day experience and ordering of the city. This paper brings economic incentives, based on comprehensive proposals, on the relationship between energy consumption and resilience enhancement policies. In the light of the high policy importance of both urban planning and transportation system function in the urban environment, and the lack of large sample empirical analyses, we believe this paper provides a significant contribution to the extant literature and to the policy debate. Furthermore, combining information on the urban transport system in which resilience concept, we able to provide a tentative interpretation of the mechanisms through which the effects on the home transportation manifest. These results are consistent with theoretical arguments suggesting that, whereas increasing use of resilience enhancement mechanism allows adapting existing transportation system to access new or complementary forms of urban management it may also determine a dilution of specific resources, deterioration of integrative capabilities and the need of greater supervision by managers. Although, more a matter of interpretation than flowing directly from the analysis, it also seems worth speculating or assuming that resilience urban planning is correlated with urban transportation productivity. This does not stem directly from data about urban planning activities but reflects the information gathered about urban public policy on knowledge commercialization and innovation investments about resilience concept. It seems plausible that successful transportation system productivity policies work in generalized way. The most effective actions are those which are complementary to private investment and in particular provide local public transportation, recognizing both that private sector will not provide such services in optimal quantities without public action and that they are essential as complementary inputs. Such effective public policies for resilience transportation planning activities and efficiency growth in urban transit system are likely to focus on:

- efficient investment in knowledge infrastructure in urban level for transportation system efficiency improvement;

- coordinating public decision- making process with private for promotion urban creativity activity and innovation transportation system to create resilient communities capable of facing risks with greater flexibility;

- assisting the maintenance of flexibility of urban regions through definition public_ private partnership projects in transportation field;

- the provision of appropriate amenities for resilience transportation planning activities in urban regions level. 
This paper has shown that efforts are essential to be made by cities toward considering resilience principles which are incorporated in the transportation planning. However, limited attempt were made to develop a comprehensive framework of resilience indicators and targets that incorporate such efficiency and climate responsiveness indicators into the transportation plans and plan evaluation. In addition, there is the need to review the approaches adopted in the planning process to a more participatory approach which will encourage and ensure adequate input into resilience transportation planning by the affected communities. The participatory approach can be enhanced by improving the level of environmental and risk management awareness of the citizens and establishing effective training program for the staff of different agencies that are involved in the transportation planning process. Essentially, an efficient and effective information system should be developed to support and integrate the resilience transportation planning system. The information system must be robust and versatile enough to incorporate a system of resilience indicators and targets especially spatial indicators which requires geographical resilience indicators analysis. The efforts of some local authorities in developing geographic information systems for cities are noteworthy and should be improved upon to incorporate environmental/ resilience flexibility information system. Overall, an effective system of institutional capacity in resilience transportation systems efficiency improvement is essential.

\section{References}

Alexander ER (2008) Between state and market: A third way of planning. International Planning Studies, 13 (2): 119-132.

Banister D (2008) The Sustainable Mobility Paradigm. Transport Policy 15: 73-80.

Barnett J (2001) Adapting to climate change in Pacific Island countries: The problem of uncertainty. World Development, 29: 977-993.

Bongardt D, Breithaupt M, Creutzig F (2010) Beyond the Fossil City: Towards Low Carbon Transport and Green Growth. Working Paper, German Technical Cooperation (GTZ). Germany: Eschborn.

Buehler R, Pucher J (2011) Making Public Transport Financially Sustainable. Transport Policy, Elsevier, 18: 126-138.

Campanella TJ (2006) Urban resilience and the recovery of New Orleans. Journal of the American Planning Association. 72(2): 141-146.

Carpenter S, Walker B, Anderies JM, Abel N (2001) From metaphor to measurement: Resilience of what to what? Ecosystems, 4: 765-781. (CCC: Committee on Climate Change. 2010. Building a low-carbon economy - the UK's innovation challenge. <http://www.theccc.org.uk>)

Christopherson S, Michie J, Tyler P (2010) Regional resilience: Theoretical and empirical perspectives. Cambridge Journal of Regions, Economy and Society, 3 (1): $3-10$.

Creutzig F, McGlynn E, Minx J, Edenhofer O (2011a) Climate policies for road transport revisited (I): Evaluation of the current framework. Energy Policy, 39(5): $2396-2406$. 
Dalkmann H, Brannigan C (2009) Module 5e: Transport and climate change. In: A Sourcebook for Policy-Makers in Developing Cities. Gesellschaft fuer Technische Zusammenarbeit (GTZ). Germany: Eschborn.

Davic RD, Welsh HH Jr (2004) On the ecological roles of salamanders. Annual Review of Ecology, Evolution, and Systematic, 35: 405-434.

Eraydin A, Taşan-Kok T (ed.) (2013) Resilience Thinking in Urban Planning. GeoJournal Library 106, DOI 10.1007/978-94-007-5476-8_2, Springer Science+Business Media Dordrecht 2013.

Ganor M, Ben-Lavy Y (2003) Community resilience: lessons derived from Gilo under fire. Journal of Jewish Communal Service Winter/Spring: 105-108.

Godschalk D (2003) Urban hazard mitigation: creating resilient cities. Natural Hazards Review 4: 136-143.

GTZ (2007) Module 5e, Transport and Climate Change. Sustainable Transport: A Sourcebook for Policy-makers in Developing Cities. Deutsche Gesellschaft fuer Technische Zusammenarbeit (GTZ). Germany: Eschborn.

Gunderson L, Holling CS (ed.) (2001) Panarchy: Understanding transformations in human and natural systems. Washington (DC): Island Press.

Gwilliam K (2005) Bus Franchising in Developing Countries: Some Recent World Bank Experience. Revised keynote paper, 8th International Conference on Ownership and Regulation of Land Passenger Transport, June 2003. Rio de Janeiro, Brazil.

Harvey D (2005) A brief history of neoliberalism. Oxford/New York: Oxford University Press.

Hickman R, Hall P, Banister D (2013) Planning more for sustainable mobility, Journal of Transport Geography, 33: 210-219.

Hidalgo D, Carrigan A (2010) Modernizing Public Transportation: Lessons Learned From Major Bus Improvement in Latin America and Asia. EMBARQ Report, 2010, [Online] available from: World Resources Institute. Available from: http://www. embarq.org/sites/default/fi les/EMB2010_ BRTREPORT.pdf (accessed 8 June 2011).

Holling C (1973) Resilience and stability of ecological systems. Annual review of ecology and systematics 4: 1-23.

IEA (2009a) CO 2 Emissions from Fuel Combustion. International Energy Agency (IEA). Paris.

Jessop B (1993) Towards a Schumpeterian workfare state? Preliminary remarks on post-fordist political economy. Studies in Political Economy. 40(1): 7-40.

Kinney P, Gatari Gichuru M, Volavka-Close N, Ngo N, Ndiba P, Law A, Gachanja A, Mwaniki Gaita S, Chillrud S, Sclar E (2011) Traffic impacts on PM2.5 air quality in Nairobi, Kenya. Environmental Science \& Policy 14, (4)(6): 369-78.

Leitner H, Sheppard ES, Sziarto K, Maringanyi A (2007) Contesting urban futures: Decentering neoliberalism. In: H Leitner, J Peck, ES Sheppard (Eds.), Contesting neoliberalism: Urban frontiers. New York: The Guilford Press: 1-26.

Ludwig D, Walker B, Holling CS (1997) Sustainability, stability, and resilience. Conservation Ecology. Available from: http://www.consecol. org/vol1/iss1/art7/.

Martin-Breen P, Marty Anderies J (2011) Resilience: A literature review. The Rockefeller Foundation.

McKinsey Global Institute (2009) Averting the Next Energy Crisis: The Demand Challenge. San Francisco, CA: McKinsey Global Institute.

Nakanishi H, Matsuo K, Black J (2013) Transportation planning methodologies for post-disaster recovery in regional communities: the East Japan Earthquake and tsunami 2011. Journal of Transport Geography. 31(2013): 181-191. 
Vol. 2, No. $3 \quad$ Khodabakhsh et al.: An Analytical View on Resilience Urban...

Peck J, Theodore N, Brenner N (2009) Neoliberal urbanism: Models, moments, mutations. SAIS Review. 29(1): 49-66.

Pickett STA, Cadenasso ML, Grove JM (2004) Resilient cities: Meaning, models, and metaphor for integrating the ecological, socio-economic and planning realms. Landscape and Urban Planning. 69(1): 369-384.

Purcell M (2009) Resisting Neoliberalization: Communicative planning or counterhegemonic movements?. Planning Theory. 8(2): 140-165.

Qin XY, Prather KA (2006) Impact of biomass emissions on particle chemistry during the California Regional Particulate Air Quality Study, Int. J. Mass Spectrom., 258(1-3): 142-150.

Raco M, Street E (2012) Resilience Planning, Economic Change and the Politics of Postrecession Development in London and Hong Kong. Urban Studies. 49(5): $1065-1087$.

Reis K (2013) Re-Conceptualizing Community Resilience in Australian Disaster Risk Management. In: Conference CD - Rom, Sydney, Climate Adaptation 2013 Knowledge + Partnership, 25-27 June, 2013.

Sapountzaki K, Wanczura S, Casertano G, Greiving S, Xanthopoulos G, Ferrara FF (2011), Disconnected Policies and Actors and the Missing Role of Spatial Planning throughout the Risk Management Cycle. Natural Hazards. 59(3): 14451474.

Schipper L, Marie-Lilliu M (1999) Transport and CO2 Emissions: Flexing the LinkA Path for the World Bank. Environment Department Paper No. 69. Washington, DC: World Bank.

Stern N (2007) The Economics of Climate Change: The Stern Review. Cabinet Office, HM Treasury. New York: Cambridge University Press.

Suarez P, Anderson W, Mahal V, Lakshmanan TR (2005) Impacts of flooding and climate change on urban transportation: a system wide performance assessment of the Boston Metro Area. Transportation Research Part D: Transport and Environment. 10(3): 231-244.

Tiwari G (2006) Urban Passenger Transport: Framework for an Optimal Mix. India Resident Mission Policy Brief Series No. 1. New Delhi, India: Asian Development Bank (ADB).

UN (2009) World Urbanization Prospects: The 2009 Revision. Population Division of the Department of Economic and Social Affairs of the United Nations Secretariat, New York.

UNDP (2010) Human Development Report 2010 - The Real Wealth of Nations: Pathways to Human Development. United Nations Development Program (UNDP). New York: Palgrave, Macmillan.

Walker B, Salt D, Reid W (2006) Resilience thinking: Sustaining ecosystems and people in a changing world. Washington, DC: Island Press.

WBCSD (2002) Mobility 2001: World Mobility at the End of the Twentieth Century and Its Sustainability. Geneva: World Business Council for Sustainable Development (WBCSD). 